\title{
ANALISIS GAYA BAHASA DALAM LIRIK LAGU "LENKA KRIPAC" ALBUM LENKA
}

\author{
Miftahurrohman $^{1}$, Rr.Astri Indriana Octavita ${ }^{2}$, Ira Miranti $^{3}$ \\ 1,2,3 Universitas Indraprasta PGRI \\ Jl.Nangka Raya No.58 C Tanjung Barat, Jakarta Selatan 12530, Indonesia \\ Corresponding Author $(S)$ :
}

\begin{abstract}
:
The aims of this research are to describe figurative language and meaning of figurative language. The method of this research is descriptive qualitative method which analyzes figurative language. The result of this research is to find the figurative language song lyric Lenka Kripac. The results are repetisi with percentage 22,7\%. Antisipasi, koreksio, sinisme, and koreksio are $2,3 \%$.
\end{abstract}

Keywords: Figurative Language, Song, Music, Lyric

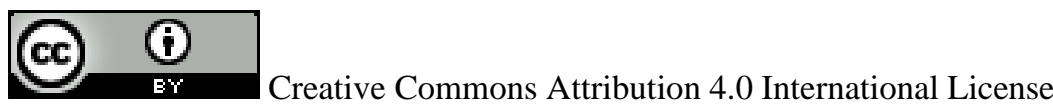

\section{PENDAHULUAN}

Bahasa adalah suatu sistem lambang bunyi, bersifat arbitrer, digunakan oleh suatu masyarakat tutur untuk bekerja sama, berkomunikasi, dan mengidentifikasi diri. Betapa pentingnya bahasa bagi manusia kiranya tidak perlu diragukan. Hal itu tidak dapat dibuktikan dengan menunjukkan pemakaian bahasa dalam kehidupan sehari-hari, tetapi dapat juga dibuktikan dengan melihat banyaknya perhatian para ilmuan dan praktisi terhadap bahasa. Bahasa adalah alat komunikasi antara anggota masyarakat berupa simbol bunyi yang dihasilkan oleh alat ucap manusia. Bahasa di bagi menjadi dua, bahasa lisan dan tulis. Bahasa tersebut memiliki hubungan yang erat satu dengan yang lain. Bahasa tulis digunakan sebagai salah satu alat komunikasi yang digunakan dalam berbagai situasi komunikasi dan memiliki tujuan yang berbeda. Setiap situasi dan tujuan yang berbeda, memungkinkan penutur dalam bahasa tulis memilih variasi bahasa yang digunakan.

Gambaran ekspresi perasaan tersebut dapat disalurkan dengan melalui bentuk karya seni seperti lagu. Lagu adalah penyampaian ulasan suatu hal dalam bentuk perasaan dan keadaan dengan menggunakan nada-nada yang membentuk harmonisasi sebagai sarananya. Dalam kehidupan sehari-hari, lagu adalah bentuk hiburan yang dapat mewakili perasaan dari isi hati seseorang. Menurut Moeliono (2007: 624) lagu adalah ragam suara yang berirama. Lagu merupakan hasil hasir karya seni hubungan dari seni suara dan seni bahasa, sebagai karya seni suara melibatkan melodi dan warna suara penyanyi. Dalam Kamus Besar Bahasa Indonesia (Ardiani M, 2009: 7-8) lagu adalah berbagai irama yang 
meliputi suara instrument dan bernyanyi, nyanyian, dan tingkah laku. Lagu adalah berbagai irama yang meliputi suara instrument dan bernyanyi dan sebagainya, nyanyian, tingkah laku, cara, lagak (KBBI, 2003: 401).

Dalam suasana apapun, lagu dapat menyesuaikan suasana hati pendengarnya. Saat ini begitu banyak versi lagu yang bisa menggambarkan suasana hati senang, sedih, jatuh cinta, rasa semangat, kehilangan, dan semua itu terlampir dalam berbagai aliran musik. Pengarang lagu tidak hanya melihat makna semata, melainkan mewujudkan suatu perasaan yang mampu membuat perasaan pendengarnya seperti yang telah disebutkan. Untuk itu pengarang menyusun kata-kata menjadi lirik lagu untuk menciptakan suasana yang diharapkan dan terdengar indah. Oleh karena itu, terkadang bahasa yang digunakan merupakan bahasa yang tidak cocok dipakai secara umum. Keindahan yang diciptakan oleh pengarang dalam lirik lagu secara alami mampu memotivasi, menginspirasi, dan imajinasi pendengarnya.

Lirik merupakan ekspresi seseorang dari dalam batinnya tentang sesuatu hal baik yang sudah dilihat, didengar, maupoun dialami. Lirik lagu memiliki kekhususan dan ciri tersendiri dibandingkan dengan sajak karena penuangan ide lewat lirik lagu diperkuat dengan melodi dan jenis irama yang disesuaikan dengan lirik lagu (Ardiani M, 2009: 9). Semi (2009: 106) lirik lagu adalah puisi yang dinyanyikan, karena itu ia disusun dengan susunan yang sederhana dan mengungkapkan sesuatu yang sederhana pula. Selain itu, Suprapto (2006: 46) lirik adalah karya sastra yang berisi curhatan pribadi, bersifat subjektif, didasarkan pada rasa kasih sayang, rindu dendam, suka dan benci, dan sebagainya.

Menurut Noor (2004: 24) lirik lagu merupakan ungkapan seorang pengarang. Lirik yang dikenal yakni karya sastra yang berisi ekspresi (curahan) perasaan pribadi yang lebih mengutamakan cara mengekspresikannya. Menurut Muliono (2007: 678) lirik lagu mempunyai dua pengertian yaitu: 1 . Karya sastra (puisi) yang berisi curahan perasaan pribadi. 2. Susunan sebuah nyanyian. Dalam menggunakan lirik seorang penyair/pencipta lagu itu harus benar-benar pandai dalam mengolah kata. Berdasarkan pengertian diatas dapat dikatakan bahwa lirik lagu adalah sekumpulan kata yang puitis dengan menggunakan gaya bahasa yang indah dan akan dibawakan oleh seorang penyanyi yang diiringi dengan lantunan musik yang indah dan merdu, sehingga pesan yang ingin disampaikan oleh sang pencipta lagu dapat diterima oleh para pendengarnya.

Gaya bahasa selalu digunakan untuk menambah keragaman suatu kalimat saat berbahasa. Gaya bahasa menjadi celah untuk manusia dalam menyalurkan kreatifitas, perasaan emosi, dan ekspresi berbahasa yang kuat. Gaya bahasa sebenarnya sudah sangat terkenal dan sudah terdengar di telinga kita dalam kehidupan sehari-hari, namun terkadang kita tidak sadari hal itu. Menurut Albertine (2005:51) mengemukakan, gaya bahasa adalah bahasa yang bermula dari bahasa yang biasa digunakan dalam gaya tradisional dan literal untuk menjelaskan orang atau subjek. Dengan menggunkan gaya bahasa, pemaparan imajinatif menjadi lebih segar dan berkesan. Endraswara (2003:73) juga menyatakan bahwa gaya bahasa merupakan efek seni dalam sastra yang dipengaruhi juga oleh nurani. Melalui gaya bahasa itu seseorang sastrawan akan menuangkan ekspresinya. Betapa pun rasa jengkel dan senangnya, jika dibungkus dengan gaya bahasa akan semakin indah. Berarti gaya bahasa adalah pembungkus ide yang akan menghaluskan teks sastra. 
Gaya bahasa mempunyai cakupan yang luas. Kemudian Ratna (2009: 22) menyatakan bahwa gaya bahasa adalah ekspresi linguistis, baik dalam puisi maupun prosa (cerpen, novel, dan drama). Gaya bahasa sering disebut majas, menurut Finoza (2010: 135) majas adalah penutur mengungkapkan maksudnya. Sedangkan menurut Tarigan (2009: 4) menyatakan gaya bahasa adalah bentuk retorik, yaitu penggunaan kata-kata dalam berbicara dan menulis untuk meyakinkan atau mempengaruhi penyimak dan pembaca. Kata retorik berasal dari bahasa Yunani rhetor yang berarti orator atau ahli pidato. Dari pendapat ahli, penulis berpendapat bahwa gaya bahasa adalah bentuk ungkapan bahasa yang menyimpang dari bentuk sehari-hari yang digunakan pengarang untuk meyakinkan dan mempengaruhi penyimak dan pembaca.

Menurut Irwan Saragih dalam buku bahasa Indonesia (2015: 63) gaya bahasa atau langgam bahasa, sering juga kita sebut majas adalah cara penutur mengungkapkan maksudnya. Ada cara yang memakai perlambangan (majas, personifikasi); ada cara yang menekankan kehalusan (majas eufemisme, litotes); dan masih banyak lagi yang lainnya. Gaya bahasa dikenal dalam retorika dengan istilah style dari kata Latin. Jadi style atau gaya bahasa sebagai cara mengungkapkan pikiran melalui bahasa secara khas yang memperlihatkan jiwa dan kepribadian penulis. Gaya bahasa adalah pengungkapan ide, gagasan, pikiran-pikiran seorang penulis yang meliputi hierarki kebahasaan yaitu kata, frasa, klausa, bahkan wacana untuk menghadapi situasi tertentu (Rahayu, 2005: 11).

Jadi secara garis besar gaya bahasa adalah ungkapan pikiran melalui bahasa yang khas. Setiap pengarang mempunyai gaya bahasa dan cara sendiri dalam membuat suatu pikiran. Berdasarkan pendapat para ahli di atas dapat disimpulkan bahwa gaya bahasa yaitu bahasa yang digunakan oleh pengarang dalam penyampaian ide, gagasan pengarang terhadap karya sastranya dan juga majas merupakan dari gaya bahasa.

Gaya bahasa dalam lirik lagu cenderung ditentukan oleh pilihan kata dan jenis gaya bahasanya. Mengingat banyaknya jenis gaya bahasa yang ada, berikut ini adalah penjelasan dari beberapa jenis gaya bahasa yang digunakan peneliti dalam menganalisis gaya bahasa pada lirik lagu Lenka Kripac dalam album Lenka. Menurut Tarigan (2009: 6) berpendapat bahwa gaya bahasa di kelompokkan atas empat kategori, yaitu gaya bahasa perbandingan, perulangan, pertautan, dan pertentangan.

Pembagian mengenai gaya bahasa juga diungkapkan oleh Rachmat Djoko Pradopo (2009: 95) bahwa gaya bahasa meliputi: tautologi, pleonasme, enumerasi, pararelisme, retorik, retisense, hiperbola, paradox, dan kiasmus. Menurut Semi (2010: 53-56) mengemukakan tentang macam-macam gaya bahasa yang dapat digunakan yaitu: inversi, repetisi, koreksi, klimaks, anti klimaks, antithesis, pertanyaan retoris, alusio, pararelisme, sarkasme, simbolik, pleonasme, paradoks, proterito, asyndeton, dan polisendeton. Jadi gaya bahasa menurut Semi terbagi menjadi 16 jenis. Sedangkan menurut Keraf (2010: 129) "Gaya bahasa berdasarkan makna diukur dari langsung tidaknya makna. Bila acuan yang digunakan itu masih mempertahankan makna dasar, maka bahasa itu masih bersifat polos. Tetapi bila sudah berubah makna entah konotatif atau denotative maka acuan itu dianggap sudah memiliki gaya sebagai yang dimaksudkan”.

Menurut Nurhayati (2009: 3) semantik berkedudukan sebagai salah satu cabang ilmu linguistik yang mempelajari tentang makna suatu kata dalam bahasa, sedangkan linguistik 
merupakan ilmu yang mengkaji bahasa lisan dan tulisan yang memiliki ciri-ciri sistematik, rasional, dan empiris. Menurut Chaer (2007: 284) makna sebagai objek dari tataran linguistik yang berada di tataran fonologi, morfologi, dan sintaksis. Harimurti Kridalaksana (Kamus Linguistik, 2008: 193) pengertian makna adalah bagian struktur bahasa yang berhubungan dengan makna ungkapan dan juga dengan struktur makna. Sutedi (2003: 111) makna memegang peranan penting dalam berkomunikasi. Disebabkan bahasa memiliki fungsi dan tujuan untuk digunakan dalam berkomunikasi dalam menyampaikan suatu makna. Sedangkan menurut Keraf (2004: 28) makna dibedakan atas makna kata yang bersifat denotatif dan makna kata yang bersifat konotatif. Makna denotatif adalah makna dalam alam wajar secara eksplisit. Makna wajar ini adalah makna yang sesuai dengan apa adanya. Makna ini disebut juga makna proposional karena ia bertalian dengan informasi-informasi yang bersifat faktual. Makna konotatif adalah suatu jenis makna dimana stimulus dan respons mengandung nilai-nilai emosional. Dengan kata lain, kata yang mengandung arti tambahan, perasaan tertentu, atau nilai rasa tertentu disamping makna dasar yang umum dinamakan makna konotatif.

\section{METHOD}

Metode yang digunakan dalam penelitian ini adalah metode deskriptif kualitatif, yaitu membuat sesuatu yang sistematis, faktual, dan akurat mengenai fakta-fakta dan sifat-sifat hubungan atau daerah tertentu (Suryabrata, 2003: 75). Teknik dalam penelitian ini menggunakan teknik analisis data. Data ini diambil dari lagu yang terdapat dalam album "Lenka", ini akan dianalisis dan diselesaikan sesuai teori yang digunakan oleh peneliti. Teknik analisis data yang dilakukan dalam penelitian ini, adalah dengan cara menerjemahkan terlebih dahulu lirik lagu pada album "Lenka" dalam Bahasa Indonesia dengan tujuan untuk mempermudah peneliti dalam menganalisis gaya bahasa dan makna yang terkandung di dalam lagu pada album "Lenka" Kemudian, peneliti menghimpun dan menganalisis gaya bahasa dan makna setiap kalimat yang terdapat dalam bait lirik lagu pada album "Lenka".

\section{HASIL DAN DISKUSI}

Berdasarkan hasil analisis data mengenai penggunaan gaya bahasa yang dilakukan oleh peneliti pada 12 lirik lagu pada album Lenka karya Lenka Kripac, ditemukan terdapat 44 data penggunaan gaya bahasa. 44 data penggunaan gaya bahasa tersebut antara lain terdiri dari 8 data aliterasi, 9 data asonansi, 8 data hiperbola, 3 data litotes, 2 data personifikasi, 10 data repetisi, 1 data antisipasi, 1 data koreksio, 1 data sinisme, dan 1 data sinekdoke. Sedangkan untuk jenis gaya bahasa yang jarang muncul adalah gaya bahasa antisipasi, koreksio, sinisme, dan sinekdoke. Kemudian, penggunaan makna denotatif sebanyak 31 data dan penggunaan makna konotatif sebanyak 13 data. Selanjutnya hasil analisis gaya bahasa dan makna pada seluruh lagu dapat dilihat pada tabel berikut:

Tabel 1 Analisis Gaya Bahasa

\begin{tabular}{|c|c|c|c|c|c|c|c|c|c|c|c|c|}
\hline \multirow[b]{2}{*}{ No } & \multirow[b]{2}{*}{ Judul lagu } & \multicolumn{10}{|c|}{ Gaya Bahasa } & \multirow[b]{2}{*}{ Jumlah } \\
\hline & & 1 & 2 & 3 & 4 & 5 & 6 & 7 & 8 & 9 & 10 & \\
\hline 1 & The Show & 2 & 2 & 2 & 0 & 0 & 0 & 0 & 0 & 0 & 0 & 6 \\
\hline 2 & Trouble is a friend & 2 & 3 & 0 & 0 & 0 & 2 & 0 & 0 & 0 & 0 & 7 \\
\hline 3 & Like a song & 0 & 2 & 1 & 0 & 0 & 0 & 0 & 0 & 0 & 0 & 3 \\
\hline 4 & Skip along & 2 & 1 & 1 & 0 & 0 & 1 & 0 & 0 & 0 & 0 & 5 \\
\hline 5 & Don't let me fall & 1 & 0 & 0 & 0 & 0 & 3 & 0 & 0 & 0 & 0 & 4 \\
\hline
\end{tabular}




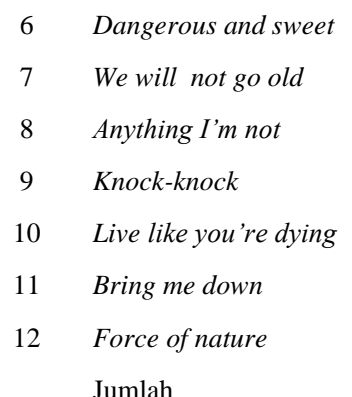

$\begin{array}{lllllllllll}1 & 0 & 2 & 0 & 0 & 0 & 0 & 0 & 1 & 0 & 4 \\ 0 & 1 & 0 & 0 & 0 & 2 & 0 & 0 & 0 & 0 & 3 \\ 0 & 0 & 0 & 3 & 0 & 0 & 0 & 0 & 0 & 0 & 3 \\ 0 & 0 & 0 & 0 & 1 & 1 & 0 & 0 & 0 & 0 & 2 \\ 0 & 0 & 1 & 0 & 0 & 1 & 0 & 1 & 0 & 1 & 4 \\ 0 & 0 & 0 & 0 & 0 & 0 & 1 & 0 & 0 & 0 & 1 \\ 0 & 0 & 1 & 0 & 1 & 0 & 0 & 0 & 0 & 0 & 2 \\ 8 & 9 & 8 & 3 & 2 & 10 & 1 & 1 & 1 & 1 & 44\end{array}$

Keterangan:

1. Aliterasi

4. Litotes

2. Asonansi

5. Personifikasi

3. Hiperbola

6. Repetisi

7. Antisipasi

10. Sinekdoke

8. Koreksio

9. Sinisme

Tabel 2 Makna Denotatif dan Konotatif

\begin{tabular}{clccc}
\hline \multirow{2}{*}{ No Judul Lagu } & \multicolumn{2}{c}{ Jumlah } \\
\cline { 3 - 4 } & & Denotatif & Konotatif & \\
\hline 1 & The show & 4 & 2 & 6 \\
2 & Trouble is a friend & 7 & 0 & 7 \\
3 & Like a song & 2 & 1 & 3 \\
4 & Skip along & 4 & 1 & 4 \\
5 & Don't let me fall & 4 & 0 & 4 \\
6 & Dangerous and sweet & 1 & 3 & 3 \\
7 & We will not go old & 3 & 0 & 3 \\
8 & Anything I'm not & 3 & 1 & 2 \\
9 & Knock-knock & 1 & 2 & 4 \\
10 & Live like you're dying & 2 & 1 & 1 \\
11 & Bring me down & 0 & 2 & 2 \\
12 & Force of nature & 0 & 13 & 44 \\
\hline
\end{tabular}

Berdasarkan hasil data analisis yang telah diperoleh, maka dapat diketahui bahwa penggunaan gaya bahasa banyak terdapat pada lirik lagu Trouble is a friend yaitu sebanyak 7 data, yang terdiri dari 2 data asonansi, 3 data hiperbola, 2 data repetisi, dan 7 data makna denotatif serta pada lirik lagu The Show yaitu sebanyak 6 data, yang terdiri dari 2 data aliterasi, 2 data asonansi, 2 data hiperbola, 4 data makna denotatif dan 2 data makna konotatif. Sementara penggunaan gaya bahasa paling sedikit di temukan pada lirik lagu Bring me down yaitu sebanyak 1 data saja yang terdiri dari 1 data antisipasi dan 1 data makna konotatif.

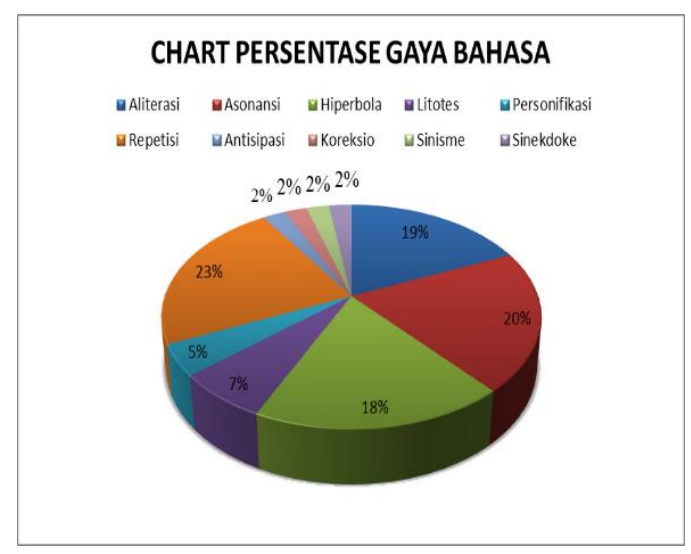


Grafik 1 Persentase Gaya Bahasa

Berdasarkan hasil temuan data tersebut, maka rekapitulasi hasil temuan gaya bahasa yang terdapat pada lirik lagu dalam album Lenka karya Lenka Kripac dapat disimpulkan yaitu terdapat sebanyak 8 data atau 18,2\% penggunaan jenis gaya bahasa aliterasi, sebanyak 9 data atau 20,4\% penggunaan jenis gaya bahasa asonansi, sebanyak 8 data atau $18,2 \%$ penggunaan jenis gaya bahasa hiperbola, sebanyak 3 data atau $6,8 \%$ penggunaan jenis gaya bahasa litotes, sebanyak 2 data atau 4,5\% penggunaan jenis gaya bahasa personifikasi, sebanyak 10 data atau $22,7 \%$ penggunaan jenis gaya bahasa repetisi, sebanyak 1 data atau 2,3\% penggunaan jenis gaya bahasa antisipasi, sebanyak 1 data atau $2,3 \%$ penggunaan jenis gaya bahasa koreksio, sebanyak 1 data atau 2,3\% penggunaan jenis gaya bahasa sinisme, sebanyak 1 data atau $2,3 \%$ penggunaan jenis gaya bahasa sinekdoke.

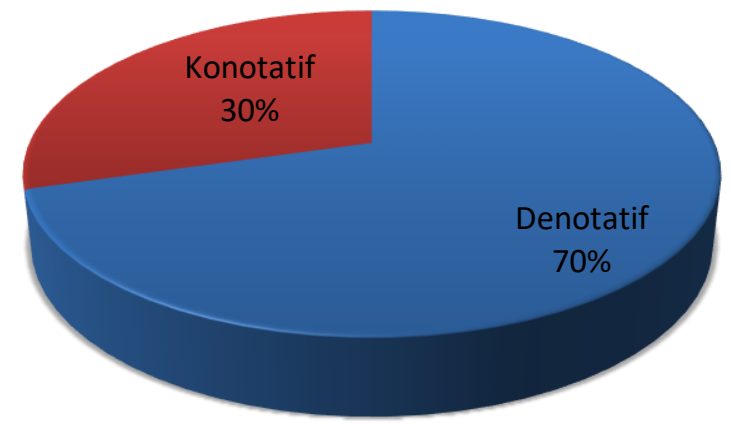

Grafik 2 Makna Denotatif dan Konotatif

Berdasarkan hasil temuan data tersebut, maka rekapitulasi hasil temuan makna yang terdapat pada lirik lagu dalam album Lenka karya Lenka Kripac dapat disimpulkan yaitu terdapat sebanyak 31 data atau 70\% penggunaan jenis makna denotatif dan sebanyak 13 data atau $30 \%$ penggunaan jenis makna konotatif.

Dari seluruh hasil analisis data persentase temuan yang ditemukan oleh peneliti dapat disimpulkan bahwa terdapat 44 data penggunaan gaya bahasa pada 12 lirik lagu dalam album Lenka karya Lenka Kripac. Jenis gaya bahasa yang sering digunakan adalah gaya bahasa repetisi yaitu 10 data atau $22,7 \%$. Sedangkan untuk jenis gaya bahasa yang jarang digunakan adalah gaya bahasa antisipasi, koreksio, sinisme, dan sinekdoke yaitu 1 data atau 2,3\%. Penggunaan jenis makna denotatif sebanyak 31 data atau $70 \%$ dan makna konotatif sebanyak 13 data atau $30 \%$.

\section{SIMPULAN}

Dari hasil penelitian tentang penggunaan gaya bahasa pada lirik lagu dalam album Lenka karya Lenka Kripac, maka kesimpulannya sebagai berikut. Pertama, terdapat 44 data penggunaan gaya bahasa pada 12 lirik lagu dalam album Lenka karya Lenka Kripac. Kedua, jenis gaya bahasa yang sering muncul adalah gaya bahasa repetisi yaitu sebanyak 10 data atau $22,7 \%$. Sedangkan untuk jenis gaya bahasa yang jarang muncul adalah gaya bahasa antisipasi, koreksio, sinisme, dan sinekdoke yaitu sebanyak 1 data atau 2,3\%. Ketiga, penggunaan gaya bahasa terbanyak di temukan pada lirik lagu Trouble is a friend yaitu sebanyak 7 data, yang terdiri dari 2 data aliterasi, 3 data asonansi, dan 2 data repetisi. 
Sementara penggunaan gaya bahasa paling sedikit ditemukan pada lirik lagu Bring me down yaitu sebanyak 1 data antisipasi.

\section{UCAPAN TERIMA KASIH}

Terima kasih kepada tim editorial Jurnal JEdu atas terbitnya artikel hasil penelitian ini. Terimakasih juga penulis ucapkan kepada semua pihak yang membantu proses penulisan artikel ini.

\section{REFERENSI}

Badudu, J.S. (2009). Kamus kata-kata serapan bahasa asing dalam bahasa Indonesia. Jakarta: PT. Kompas Media Nusantara

Chaer, A. (2012). Linguistik umum. Jakarta: Rineka Cipta.

Departemen Pendidikan Nasional. (2008). Kamus besar bahasa Indonesia. Jakarta: Rineka Cipta.

Endaswara, S. (2003). Metodologi penelitian sastra. Yogyakarta: Pustaka Widyatama.

Hasanah, R. U. (2012). Analisis gaya bahasa dalam album adele 21. Skripsi. Program Sarjana, Universitas Indraprasta PGRI, Jakarta.

Keraf, G. (2010). Diksi dan gaya bahasa. Jakarta: PT. Gramedia Pustaka Utama.

Kridalaksana, H. (2009). Kamus linguistik. Jakarta: PT. Gramedia Pustaka Utama.

Muslimah, H. (2013). Analisis Gaya bahasa pada lirik lagu dalam album midsummer station karya Owl City. Skripsi. Program Sarjana, Universitas Indraprasta PGRI, Jakarta.

Nurgiantoro, B. (2007). Teori pengkajian fiksi. Yogyakarta: Gadjah Mada University Press.

Nurhayati. E. (2009). Sosiolinguistik kajian kode tutur dalam wayang kulit. Yogyakarta: Kanwa Publisher.

Pradopo, R. D. (2009). Pengkajian puisi. Yogyakarta: Gadjah Mada University Press.

Saragih, I. (2015). Buku bahasa Indonesia. Jakarta: Universitas Indraprasta PGRI.

Semi, A. (2009). Metode penelitian sastra. Bandung: Angkasa.

Soegiyono. (2009). Pendekatan kuantitatif dan kualitatif. Bandung: Alfabeta.

Soegiyono. (2016). Metode penelitian kualitatif, kuantitatif, dan R\&D. Bandung: Alfabeta.

Sudarsana, G. (2007). Pedoman umum ejaan bahasa Indonesia yang disempurnakan. Yogyakarta: Indonesia Tera.

Tarigan, H. G. (2009). Pengajaran gaya bahasa. Bandung: Angkasa.

terjemahan-lirik-lagu-barat. (2021). Diakses Dari https://terjemahan-lirik-lagubarat.blogspot.co.id

Tim Penyusun. (2015). Pedoman penulisan skripsi/tugas akhir. Jakarta: Universitas Indrapasta PGRI

Zaimar, O. K. (2002). Majas dan pembentukannya. Sosial Humaniora, 6, 45-46. 